\title{
The influence of bank size on profitability: an application of statistics
}

\author{
Nanda Kumar Tharu ${ }^{1 *}$, Yogesh Man Shrestha ${ }^{2}$ \\ Department of Statistics, Tri Chandra Campus, Tribhuvan University, Nepal ${ }^{1,2}$ \\ nanda.tharu71@gmail.com ${ }^{1 *}$,shresthayogeshman@gmail.com²
}

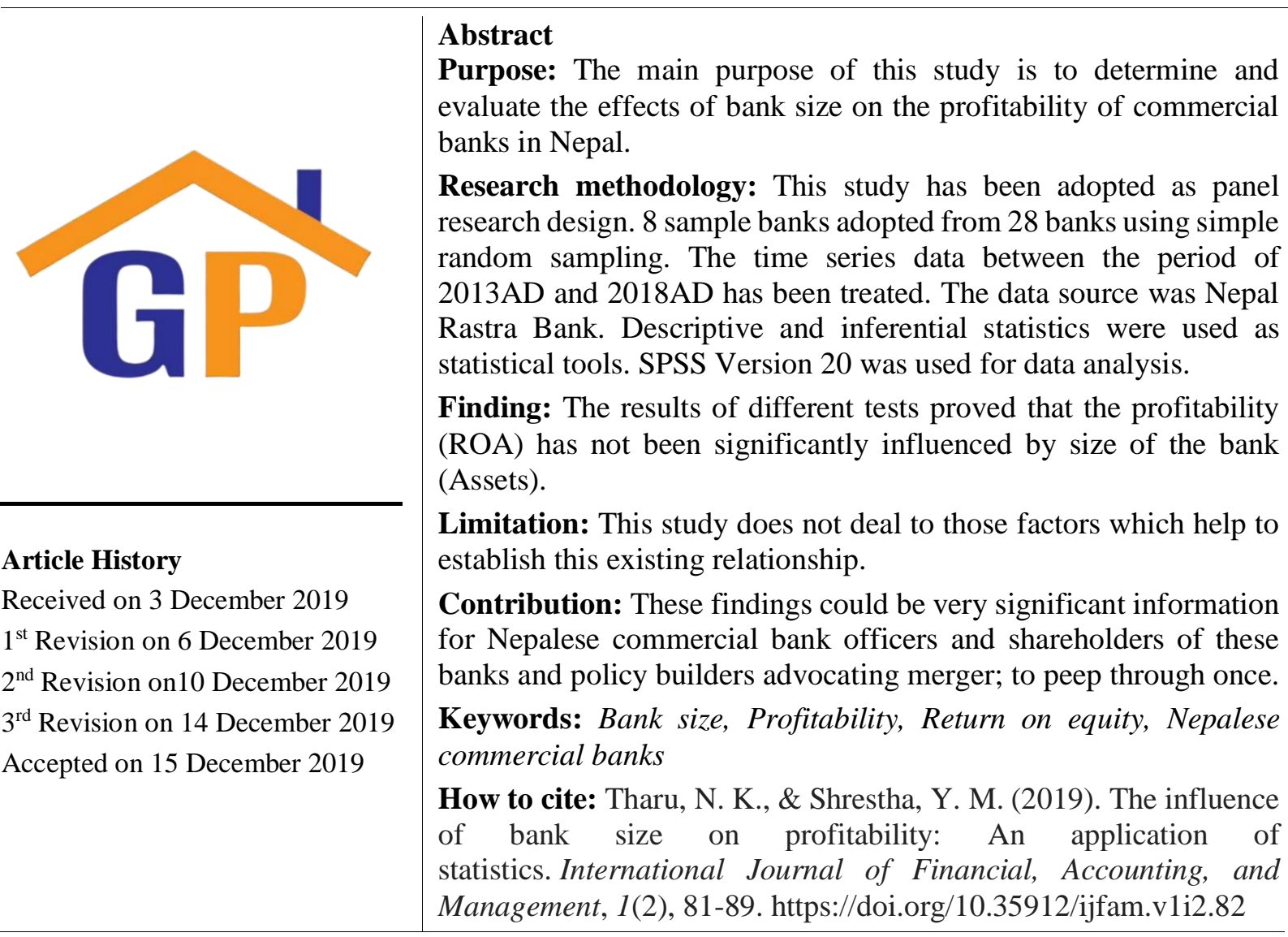

\section{Introduction}

Banking sector in all countries has an important effect on economy movements. Essential role played by banks for improvement of the overall economic activities, including out its mediation and its financial activities, are necessary for the economic growth of any country (Monnin and Jokipii, 2010).

A commercial bank is recognized as a bank that provides services such as accepting deposits, making business loans, and offering basic investment products that is operated as a business for profit. It can also refer to a bank, or a division of a large bank, which deals with corporations or large/middle-sized business to differentiate it from a retail bank and an investment bank.

The commercial bank is where most people do their banking; as opposed to an investment bank. The general role of commercial banks is to provide financial services to general public and business, hence ensuring economic and social stability and playing pivotal role for sustainable growth of the economy.

The first function of the Commercial banks is that it accepts various types of deposits from public especially from its clients, including saving account deposits, recurring account deposits, and fixed deposits. These deposits are returned whenever, the customer demands it or after a certain time period. Next, Commercial banks provide loans and advances of various forms, including an overdraft facility, cash credit, bill discounting, money at call etc. They also give demand and term loans to all types of 
clients against proper security. In most countries commercial banks are heavily regulated and this is typically done by a countries central bank. In Nepal, the commercial banks are regulated by Nepal Rastra Bank. They will impose a number of conditions on the banks that they regulate such as keeping bank reserves and to maintain minimum capital requirements.

Different types of banks have different purpose along with profitability. There are many factors influencing banks profitability with diverse ways. Aburime (2008) found that the significance of bank profitability can be judged at both micro and macro levels of the economy. At the micro level, profit is the essential prerequisite of a competitive banking institution and the cheapest source of funds. It is not merely a result, but also a necessity for successful banking in a period of growing competition on financial markets. Hence the basic aim of every bank management is to maximize profit, as an essential requirement for conducting business. At the macro level, a sound and profitable banking sector is better able to withstand negative shocks and contribute to the stability of the financial system. Bank profits provide an important source of equity especially if re-invested into the business. This should lead to safe banks, and as such high profits could promote financial stability (Flamini et al., 2009).

However, too high profitability is not necessarily good. Garcia-Herrero et al. (2007) observed that too high profitability could be indicative of market power, especially by large banks. This may hamper financial intermediation because banks exercising strong market power may offer lower returns on deposit but charge high interest rates on loans. Too low profitability, in turn, might discourage private agents (depositors and shareholders) from conducting banking activities thus resulting in banks failing to attract enough capital to operate. Furthermore, this could imply that only poorly capitalized banks intermediate savings with the corresponding costs for sustainable economic growth.

In current situation, Nepalese people are interested to invest their property in different sectors for good return. However, they are unable to select the areas of investment for proper return and suffered from loss. Some were considered a large firm gives more benefits as compared to small one, but is it true? This study tries to investigate the facts what some Nepalese people think so.

There are many aspects of the performance of commercial banks that can be analyzed. This study focuses on the profitability performance of commercial banks in Nepal. The aim of this study is to seek the effects of size of commercial bank on profitability rather than other factors for its profitability performance. Due to the finding of this study, investors get clear cut idea for investing whether to small or large scale of firms. Even though many researchers were worked on the profitability in commercial bank of Nepal, very few researchers were reported about the bank effect size on profitability in different way. The bank size is one of the factors that measure the firms' profitability.

Many researchers compared the ROE in their work. Though there are similar works, but in the present work, sizes of different banks are classified and compare their ROE mean using statistical tools to formulate sound. The fluctuation of ROE based on capital also studied in this study. This is the indication factors for investment on their own risk.

\section{Literature review and hypotheses development}

The portfolio theory approach is the most relevant and plays an important role in bank performance studies. According to the Portfolio balance model of asset diversification, the optimum holding of each asset in a wealth holder's portfolio is a function of policy decisions determined by a number of factors such as the vector of rates of return on all assets held in the portfolio, a vector of risks associated with the ownership of each financial assets and the size of the portfolio. It implies portfolio diversification and the desired portfolio composition of commercial banks are results of decisions taken by the bank management. Further, the ability to obtain maximum profits depends on the feasible set of assets and liabilities determined by the management and the unit costs incurred by the bank for producing each component of assets (Nzongang \& Atemnkeng, 2006).

\section{Bank Size}


The size of a business means the ability it possesses, the variety and number of production capability or the quantity and multiplicity of services or business it can offer concomitantly to its customers. In a simpler way, the best indication of bigness of a firm is the size of its management group or the amount of assets it possesses compared to others in the same industry (Sritharan, 2015).

Size is commonly measured by gross sales or gross value of assets, logarithm of total assets, number of employees and sales turnover. Growth in size of a firm can be in terms of revenue, profits, assets or number of employees which are all essential for increased financial health and profitability.

This study aims at identifying whether the increase or decrease in size of commercial banks asset has any influence on the bank profitability.

\section{Profitability}

Bank profits are explained by both internal and external determinants. The factors however, vary from bank to bank because of differences in shareholder and managerial decisions and activities. Previous studies suggest that capital size, size of deposit liabilities, size and composition of bank's credit portfolio, interest rate policy, exposure to risk, management quality, labor productivity, bank size, bank age, ownership, ownership concentration, and structural affiliation among others influences bank profitability.

From the poised research works, bank profitability has been measured using several ratios such as: return on assets (ROA) (Flamini et al., 2009), return on equity (Saona, 2011) and the net interest margin (Naceur \& Goaied, 2008).

\section{Bank Size and Profitability}

Firm size has been remarkably considered as an important determinant of firm profitability. Larger firms are said to be able to produce goods more cheaply as compared to small firms. This is because the former have achieved more learning, greater cumulative experience and they are able to spread their fixed costs over a greater amount of production (Kigen, 2014).

In existing literature, size has been considered as a fundamental variable in explaining firm profitability by and a number of studies on the relationship between these two conclude that impacts of size on profitability can be negative or positive. Results by Mule, Mukras and Nzioka (2015), indicated that there is a positive significant relationship between firm size and profitability, that is, return on equity, implying that a unit change in firm size leads to an increase in return on equity of firms. Contrarily, some authors claim that size may have no or negative impacts on profitability. Shepherd (1972) found that growth in size causes a diseconomies of scale whereas Niresh and Velnampy (2014), had results showing that firm size has no profound impact on profitability of firms.

Redmond et al. (2007) studied about the effect of bank size on profitability. They were categorized banks into 5 categories according to their size of assets, the ROE ratio is used as a measure of profitability, and found that, there is a negative significant relationship between profitability and the volume of assets.

Kasimodou et al. (2006) in their study when testing the banks effectiveness of UK using the bank size as a key factor categorized UK banks for two types, large and small according to assets volume. The results of their study concluded that, small banks showed higher performance in comparison to large ones. Further, the size of bank was proved to have an effect on profitability besides other factors such as liquidity. Banks performance and usefulness of investments are always has been evaluated through the trend and pattern of profitability. Murthy (2008) tested banks 'income and profitability in the gulf cooperation council countries (GCC). Data of 78 banks were used for the years 2002 to 2008 . The study assumed many factors might affect the profitability results in the gulf region. Bank size was assumed one from the important factors that influence profitability for gulf banks. The size of the total assets was found with a significant effect on banks profitability. Some banks appeared to have high profitability relative to other banks according to some clustered created by the researcher. Recently, almost all banks were forced to enhance their services and profits due to the high increase in local and international 2019 | International Journal of Financial, Accounting, and Management/ Vol 1 No 2, 81-89. 
competition between banking markets and due to the changes in banking environment. These challenges that imposed on banks locally and internationally recently considered an important issue in emerging market to reconsider their bank ratios.

Spathis (2002) had tested the financial markets through a study conducted to investigate Greek banks, his study focused on the banks asset size effect, the aim of his study was to investigate the effectiveness of large and small Greek banks through investigating (ROE) as a profitability measure and its relationship with some factors classification such as assets volume, liquidity and risk. Data from year1990 up to 1999 were used to discover the success factors of these banks, the results of the study proved that, large banks are more efficient than small ones; small banks are characterized by high capital yield (ROE) while large banks are characterized by high asset yield (ROA). Many studies also were continued to undertake and examine banks efficiency issue through focusing on assets size as the most important critical factor that effect profitability. Almost all of this research has been carried out in the western countries like Europe and USA. The research about this topic has been small to developing countries. Recently, some effort appeared to cover the efficiency of the financial institutions in developing countries too.

Nevertheless, few of these studies have tested the relationship between profitability and different bank size categories. Halkos and Salamouris (2004) investigated the effect of bank assets on its efficiency, they concluded from their study about Greek banks that, the higher the bank assets the higher the efficiency. Similar results were found in European banking sectors through a study of Bikker (1999). In contrast, results were shown by Darrat \& Yousif (2002) in the case of Kuwait, to those who found a negative relationship. Haron (2004) proved that, size has no significant effect on profitability measured by ROA. On the other hand, the results that reached to by Hassan \& Bashir (2003) proved that, size has a negative relationship on profitability.

This study specifically investigates whether size, measured by the logarithm of total assets has effects on profitability of commercial banks in Nepal or not. The review of literature reveals controversial impact of bank size on profitability. This entails the development of hypothesis associated to commercial banks.

\section{Research methodology}

The main objective of this study is to determine and evaluate the effects of bank size on the profitability of commercial banks in Nepal. This study has adopted an explanatory approach via panel research design. The population of this study comprised of all licensed commercial banks in Nepal between the period of 2013AD and 2018AD. For this study, 8 commercial banks have been considered using simple random sampling from 28 banks. Thus, the study is based on secondary data. The data has been collected from the Nepal Rastra Bank, and websites of related banks. Mean, standard deviation (SD), minimum, maximum, and Coefficient of variation (CV) are used to see the general scenario of return of equity (profitability) and total assets. The independent t-test and ANOVA are used to compare the mean of two or more than two groups' return on equity. SPSS Version 20 is used for data analysis.

The objective is to test the study hypothesis: there are any significant differences between the profitability of commercial banks in Nepal with different asset sizes.

The sizes are grouped for three categories as shown in table 2 .

Table 2. Categorization of Assets

\begin{tabular}{|l|l|}
\hline ROE $_{1}$ & Assets above Rs. 12000 millions \\
\hline $\mathrm{ROE}_{2}$ & Assets of Rs. 8000-12000 millions \\
\hline $\mathrm{ROE}_{3}$ & Assets below Rs. 8000 millions \\
\hline
\end{tabular}


As suggested by review, the Return on Equity (ROE) has been used as measure for bank profitability of different three established categories. Therefore, the average ROE of the relevant $\mathrm{A}_{\mathrm{i}}(\mathrm{i}=1,2,3)$ bank is denoted as $\operatorname{ROE}_{\mathrm{i}}(\mathrm{i}=1,2,3)$ (where"1" represents banks with assets above Rs. 12000 million, "2" represents banks with assets of Rs. 8000-12000 Millions, and "3" represents banks with assets below Rs. 8000 millions), in table 2. Therefore the hypotheses of the study are:

\section{Hypothesis H1}

Null hypothesis, $\mathrm{H}_{0}: \mathrm{ROE}_{1}=\mathrm{ROE}_{2}$

Alternative hypothesis, $\mathrm{H}_{1}: \mathrm{ROE}_{1} \neq \mathrm{ROE}_{2}$

\section{Hypothesis $\mathbf{H 2}$}

Null hypothesis, $\mathrm{H}_{0}$ : $\mathrm{ROE}_{1}=\mathrm{ROE}_{3}$

Alternative hypothesis, $\mathrm{H}_{1}: \mathrm{ROE}_{1} \neq \mathrm{ROE}_{3}$

\section{Hypothesis $\mathbf{H 3}$}

Null hypothesis, $\mathrm{H}_{0}: \mathrm{ROE}_{2}=\mathrm{ROE}_{3}$

Alternative hypothesis, $\mathrm{H}_{1}: \mathrm{ROE}_{2} \neq \mathrm{ROE}_{3}$

The null hypothesis holds that, there is no significant difference between the mean ROE of the banks with different asset size, while the alternate hypothesis holds that there is a statistical difference between the profitability of these different sized banks.

\section{Results and discussions}

The descriptive statistics has been used to see the scenario of total assets and ROE of different sample commercial banks. The findings are presented in the table 1 below:

Table 1. Descriptive statistics of Total Assets and ROE

\begin{tabular}{lllllll}
\hline Name of Banks & Variables & Min. & Max. & Mean & Std. Dev. & CV \\
\hline Siddharth Bank Ltd & Total Assets & 4032.89 & 11986.92 & $7,546.605$ & 3193.32 & 42.31 \\
& ROE & 13.85 & 24.03 & 18.268 & 4.31 & 23.58 \\
Nabil Bank Ltd & Total Assets & 5124.20 & 16097.81 & $10,969.975$ & 5018.27 & 45.75 \\
& ROE & 20.94 & 32.78 & 25.354 & 4.92 & 19.39 \\
Citizen International Bank & Total Assets & 32221.62 & 77790.95 & $54,481.237$ & 18295.85 & 33.58 \\
& ROE & 11.52 & 22.92 & 17.334 & 4.55 & 26.28 \\
Sun Rise bank Limited & Total Assets & 2966.13 & 8394.30 & $5,623.764$ & 2273.23 & 40.42 \\
& ROE & 11.71 & 15.44 & 13.580 & 1.42 & 10.48 \\
Nepal Investment Bank & Total Assets & 86173 & 171894 & $128,602.400$ & 34488.57 & 26.82 \\
& ROE & 14.71 & 27.6 & 22.448 & 5.38 & 23.96 \\
Mega Bank Ltd & Total Assets & 2057.1 & 8206.49 & $4,329.936$ & 2443.53 & 56.43 \\
& ROE & 12.46 & 17.25 & 15.164 & 2.40 & 15.85 \\
Nepal Bank limited & Total Assets & 82740.97 & 121158 & $101,875.166$ & 15428.17 & 15.14 \\
& ROE & 25.86 & 41.97 & 32.210 & 6.48 & 20.13 \\
Laxmi Bank & Total Assets & 3498.35 & 8096 & $5,766.2$ & 1873.02 & 32.48 \\
& ROE & 8.63 & 13.2 & 11.4 & 1.86 & 16.36 \\
\hline
\end{tabular}

Source: research findings

\section{Testing of Hypothesis}

The results from descriptive and hypothesis tests for the differences between the (ROE) of the different bank size categories are presented below. The following are results obtained by applying tests.

Table 2. Comparison of mean between $\mathrm{ROE}_{1}$ and $\mathrm{ROE}_{2}$ 


\begin{tabular}{|l|c|c|c|c|}
\hline Total Assets & N & Mean & Std. Deviation & Std. Error Mean \\
\hline $8001-12000\left(\mathrm{ROE}_{2}\right)$ & 9 & 15.5556 & 5.11727 & 1.70576 \\
\hline 12001 above $\left(\mathrm{ROE}_{1}\right)$ & 18 & 21.2056 & 8.52067 & 2.00834 \\
\hline
\end{tabular}

Source: research finding

Table 2 shows the mean value of ROE. The mean of $\mathrm{ROE}_{2}$ and $\mathrm{ROE}_{1}$ are $15.56 \%$ and $21.21 \%$ respectively. The positive value for both groups $\mathrm{ROE}_{2}$ and $\mathrm{ROE}_{1}$ is profitability for banks. The mean $\mathrm{ROE}_{2}$ has been observed less as compared to $\mathrm{ROE}_{1}$.

Table 3. Test of significance for equality of mean between $\mathrm{ROE}_{2}$ and $\mathrm{ROE}_{1}$

\begin{tabular}{|l|c|c|c|c|c|c|}
\hline t-statistic & Df & p-value & $\begin{array}{c}\text { Mean } \\
\text { Difference }\end{array}$ & $\begin{array}{c}\text { Std. Error } \\
\text { Difference }\end{array}$ & \multicolumn{2}{|c|}{$95 \%$ Confidence Interval } \\
\cline { 5 - 7 } & & & & & Lower & Upper \\
\hline-1.821 & 25 & 0.081 & -5.65000 & 3.10239 & -12.03949 & 0.73949 \\
\hline
\end{tabular}

Source: research finding

In table 3 , the p-value $=0.081>0.05$, this implies that the estimate for mean difference has not been statistically significant at 5\% level of significance. This concluded that there was no statistically significance difference between the average profitability on two different groups $\left(\mathrm{ROE}_{2}\right.$ and $\left.\mathrm{ROE}_{1}\right)$.

Table 4. Comparison of mean between $\mathrm{ROE}_{1}$ and $\mathrm{ROE}_{3}$

\begin{tabular}{|l|c|c|c|c|}
\hline Total Assets (in millions) & $\mathrm{N}$ & Mean & Std. Deviation & Std. Error Mean \\
\hline below $8000\left(\mathrm{ROE}_{3}\right)$ & 13 & 20.6092 & 6.89982 & 1.91366 \\
\hline 12001 above $\left(\mathrm{ROE}_{1}\right)$ & 18 & 21.2056 & 8.52067 & 2.00834 \\
\hline
\end{tabular}

Source: research finding

Table 4 reveals the mean value of ROE that yields a positive value for both groups $\mathrm{ROE}_{3}$ and $\mathrm{ROE}_{1}$. This is the indication of profitability for banks. The mean $\mathrm{ROE}_{3}$ and $\mathrm{ROE}_{1}$ have been observed as $20.61 \%$ \& $21.21 \%$ respectively.

Table 5. Test of significance for equality of mean between $\mathrm{ROE}_{3}$ and $\mathrm{ROE}_{1}$

\begin{tabular}{|l|c|c|c|c|c|c|}
\hline t-statistic & Df & p-value & $\begin{array}{c}\text { Mean } \\
\text { Difference }\end{array}$ & \multirow{2}{*}{$\begin{array}{c}\text { Std. Error } \\
\text { Difference }\end{array}$} & \multicolumn{2}{|c|}{$95 \%$ Confidence Interval } \\
\cline { 5 - 6 } & & & & & Lower & Upper \\
\hline-0.208 & 29 & 0.837 & -0.59632 & 2.87194 & -6.47010 & 5.27745 \\
\hline
\end{tabular}

Source: research finding

In table 5 , the p-value $=0.837>0.05$, this implies that the null hypothesis is accepted and concluded that the estimate for mean difference has not been statistically significant at $5 \%$ level of significance. This indicates that there was no statistically significance difference between the average profitability on two different groups $\left(\mathrm{ROE}_{1}\right.$ and $\left.\mathrm{ROE}_{3}\right)$.

Table 6. Comparison of mean between $\mathrm{ROE}_{2}$ and $\mathrm{ROE}_{3}$

\begin{tabular}{|l|c|c|c|c|}
\hline Total assets (in millions) & $\mathrm{N}$ & Mean & Std. Deviation & Std. Error Mean \\
\hline below $8000\left(\mathrm{ROE}_{3}\right)$ & 13 & 20.6092 & 6.89982 & 1.91366 \\
\hline $8001-12000\left(\mathrm{ROE}_{2}\right)$ & 9 & 15.5556 & 5.11727 & 1.70576 \\
\hline
\end{tabular}

Source: research finding

Table 6 demonstrates the mean of return on equity of groups $\mathrm{ROE}_{2}$ and $\mathrm{ROE}_{3}$. The mean values of $\mathrm{ROE}_{3}$ and $\mathrm{ROE}_{2}$ are $20.61 \%$ \& $15.56 \%$ respectively that yields a positive value, is indicates that, profitability is occurred for banks even volume of assets is lower.

Table 7. Test of significance for equality of mean between $\mathrm{ROE}_{3}$ and $\mathrm{ROE}_{2}$ 


\begin{tabular}{|l|c|c|c|c|c|c|}
\hline t-statistic & Df & p-value & $\begin{array}{c}\text { Mean } \\
\text { Difference }\end{array}$ & \multirow{2}{*}{$\begin{array}{c}\text { Std. Error } \\
\text { Difference }\end{array}$} & \multicolumn{2}{|c|}{$95 \%$ Confidence Interval } \\
\cline { 5 - 7 } & & & & & Lower & Upper \\
\hline 1.865 & 20 & 0.077 & 5.05368 & 2.70937 & -0.59797 & 10.70532 \\
\hline
\end{tabular}

Source: Research finding

In table 7 , the estimate for difference has not been statistically significant ( $p$-value $=0.077>0.05)$, at $5 \%$ level of significance. This indicates that there were no statistically significance difference between the average profitability on two different assets groups $\left(\mathrm{ROE}_{3}\right.$ and $\left.\mathrm{ROE}_{2}\right)$.

Table 8. ANOVA of Return on Equity based on bank size

\begin{tabular}{|l|c|c|c|c|c|}
\hline Return on Equity & Sum of Squares & Df & Mean Square & F & p-value \\
\hline Between Groups & 206.070 & 2 & 103.035 & 1.892 & 0.165 \\
Within Groups & 2015.011 & 37 & 54.460 & & \\
Total & 2221.081 & 39 & & & \\
\hline
\end{tabular}

Source: Research finding

One way ANOVA is also conducted to examine the mean differences for the study variables (return on equity), The results in table 8 showed that, the F-value is 1.892 with a p-value $0.65>0.05$; this result confirms the acceptance of null hypothesis. This evidence also supports that there were no statistical difference in profitability between the three categories due to the size of bank assets.

\section{Correlation Matrix for Total Assets and Return on Equity}

Table 10 shows the correlation between variables of the total assets and bank size, the correlation matrix provides preliminary evidence about the significance correlation between profitability and assets size.

Table 10. Correlation matrix

\begin{tabular}{|l|l|l|l|}
\hline \multicolumn{2}{|l|}{} & Total Assets & Return on Equity \\
\hline \multirow{3}{*}{ Total Assets } & Pearson Correlation & 1 & 0.081 \\
\cline { 2 - 5 } & p-value & & 0.620 \\
\cline { 2 - 4 } & $\mathrm{N}$ & 40 & 40 \\
\hline
\end{tabular}

Source: research finding

The Pearson correlation coefficient is 0.081 (very weak). The p-value is $0.620>0.05$ indicates the acceptance of null hypothesis and concludes that no association between total assets and return on equity. This result also maintains the null hypothesis as other above mention test supported.

\section{Conclusion}

This study was aimed to test whether the size of a bank influences on its profitability or not. However, the results of different tests proved that the profitability has not been significantly influenced by size of the bank (assets). Haron (2004) also proved that, size has no significant effect on profitability measured by ROA. This study results were in harmony with Haron (2004) study.

This study used a two sample t-test on the means of ROE for three selected groups. The results showed that each of the samples has no statistically different means with each other. The Pearson correlation coefficient between assets and profitability is 0.081 (insignificant, $p$-value $=0.620>0.05$ ). Thus it suggests that for further analysis regression model is not valid for this study.

These findings could be very significant information for Nepalese commercial bank officers and shareholders of these banks and policy builders advocating merger loudly. The study's final conclusion 
indicates that size effect does not exist, that is small, medium and large sized banks have no effect on profitability performance. These results support the initial hypothesis that the bank assets do not affect on their profitability.

\section{Limitation and study forward}

This study only identified the impact of bank size on profitability. Whatever the relation exists, it needs to incorporate the factors that lead existing relations between study variables. What are the issues that help to establish this present relation of size on profitability? It will be the further challenges and scope of this study.

\section{Acknowledgement}

Authors would like to thank Nepal Rastra Bank Team for providing valid data and faculty of department of Statistics, Tri-Chandra College, Tribhuvan University for cooperation to carry out this paper.

\section{References}

Aburime, U. (2008). Determinants of bank profitability: Company-level evidence from Nigeria. Available from: http://ssrn.com/abstract $=1106825$.

Bikker, J. A. (1999). Efficiency in the European banking Industry: an exploratory analysis to rank countries, Research series supervision, Netherlands Central Bank, Directorate Supervision.

Darrat, A. Topez \& Yousif, T. (2002). Assessing cost and technical efficiency of banks in Kuwait. Paper presented at ERF's 8th annual conference, Cairo, Egypt.

Flamini, V., McDonald, C., \& Schumacher, L. (2009). The determinants of commercial bank profitability in Sub-Saharan Africa, International monetary fund working paper. Available from: www.imf.org/external/pubs/ft/wp/2009/wp0915.pdf.

Garcia-H., Alicia \& Wooldridge, P. D.(2007). Global and regional financial integration: progress in emerging market. BIS Quarterly review. Available at SSRN: https://ssrn.com/abstract=1458345

Halkos, G.E. \& Salamouris, D.S. (2004). Efficiency measurement of the Greek commercial banks with the use of financial ratios: a data envelopment analysis approach, Management accounting research 15(2): 201-224.

Haron, S. (2004). Determinants of Islamic bank profitability, Global journal of finance and economics USA.

Hassan, K. \& Bashir, M. (2003). Determinants of Islamic banking profitability. International seminar on Islamic wealth creation, University of Durham, U.K, 7-9.

Kigen, W. K.. (2014). The effect of firm size on profitability of insurance companies in Kenya. Unpublished MBA project. University of Nairobi.

Kosimodo, P. \& Doumpos (2006). Assessing performance factors in the UK banking sector, a multi criteria methodology, Cejour journal.

Monnin, P., \& Jokipii, T. (2010). The impact of banking sector stability on the real economy. Swiss national bank working papers, (5), 1-23.

Mule, K.R., Mukras, M.S. \&Nzioka, O. M., (2015). Corporate size, profitability and market value: an econometric panel analysis of listed firms in Kenya. European scientific journal. ISSN 18577431

Murthy, R. (2008). Forcasting and managing profitability in the gulf state banking industry. Internationaljjournal of business research, vol 8. No 4.

Naceur, B. S. \& Goaied, M. (2008). The determinants of commercial bank interest margin and profitability: Evidence from Tunisia. Frontiers in Finance and Economics, Vol. 5, No. 1, 106130. Available at SSRN: https://ssrn.com/abstract $=1538810$

Nepal Rastra Bank (2017). Bank supervision annual report 2017. Nepal Rastra Bank, Nepal.

Niresh, J. A. \& Velnampy, T., (2014). Firm size and profitability: a study of listed manufacturing firms in Sri Lanka. International journal of business and management. ISSN 1833-8119 
Nzongang, T. \& Atemnkeng, J. (2006). Market structure and profitability performance in the banking industry of CFA countries: the case of commercial banks in Cameroon. Available from: https://pdfs.semanticscholar.org/d2b0/d261c3ccb484cb1faaab0b1b43ed62f16e6e.pdf

Redmond, G. \& Bonhnsa, C. (2007). Bank size and profitability: one nation, one bank. International of business research. Vol 8. No 1.

Shepherd, W.G., (1972). The elements of market structure. The Review of Economics and Statistics, 54 (1):25-37.

Spathis \& kosimduo (2002). Assessing profitability in the Greek banking system. International transactions in operational research.

Sritharan, V., (2015). Does firm size influence on firm's profitability? Evidence from listed firms of Sri Lankan Hotels and Travels sector. Research Journal of Finance and Accounting. ISSN 22222847. 